\title{
Antioxidant and Protective Effect of Ethyl Acetate Extract of Podophyllum hexandrum Rhizome on Carbon Tetrachloride Induced Rat Liver Injury
}

\author{
Showkat Ahmad Ganie, ${ }^{1}$ Ehtishamul Haq, ${ }^{2}$ Akbar Masood, ${ }^{1}$ \\ Abid Hamid, ${ }^{3}$ and Mohmmad Afzal Zargar ${ }^{1}$ \\ ${ }^{1}$ Department of Biochemistry, University of Kashmir, Srinagar 190006, India \\ ${ }^{2}$ Department of Biotechnology, University of Kashmir, Srinagar 190006, India \\ ${ }^{3}$ Indian Institute of Integrative Medicine, Jammu (Council of Scientific and Industrial Research), India
}

Correspondence should be addressed to Mohmmad Afzal Zargar, zargarma@kashmiruniversity.ac.in

Received 30 August 2010; Accepted 25 November 2010

Copyright (C) 2011 Showkat Ahmad Ganie et al. This is an open access article distributed under the Creative Commons Attribution License, which permits unrestricted use, distribution, and reproduction in any medium, provided the original work is properly cited.

The antioxidant and hepatoprotective activities of ethyl acetate extract was carefully investigated by the methods of DPPH radical scavenging activity, Hydroxyl radical scavenging activity, superoxide radical scavenging activity, hydrogen peroxide radical scavenging activity, and its reducing power ability. All these in vitro antioxidant activities were concentration dependent, which were compared with standard antioxidants such as BHT, $\alpha$-tocopherol. The hepatoprotective potential of Podophyllum hexandrum extract was also evaluated in male Wistar rats against carbon tetrachloride- $\left(\mathrm{CCl}_{4}{ }^{-}\right)$induced liver damage. Pretreated rats were given ethyl acetate extract at 20,30, and $50 \mathrm{mg} / \mathrm{kg}$ dose prior to $\mathrm{CCl}_{4}$ administration $(1 \mathrm{~mL} / \mathrm{kg}, 1: 1$ in olive oil). Rats pretreated with $P$. hexandrum extract remarkably prevented the elevation of serum AST, ALT, LDH, and liver lipid peroxides in $\mathrm{CCl}_{4}$-treated rats. Hepatic glutathione levels were significantly increased by the treatment with the extract in all the experimental groups. The extract at the tested doses also restored the levels of liver homogenate enzymes (glutathione peroxidase, glutathione reductase, superoxide dismutase, and glutathione-S-transferase) significantly. This study suggests that ethyl acetate extract of $P$. hexandrum has a liver-protective effect against $\mathrm{CCl}_{4}$-induced hepatotoxicity and possess in vitro antioxidant activities.

\section{Introduction}

The partially reduced metabolites of oxygen and nitrogen, commonly referred to as free radicals are highly toxic and reactive. They have been postulated to be increased in majority of diseases like aging, atherosclerosis, cancer, diabetes, liver cirrhosis, cardiovascular disorders, and so forth, $[1,2]$. The most common reactive oxygen species are superoxide anion $\left(\mathrm{O}_{2} \cdot-\right)$, hydrogen peroxide $\left(\mathrm{H}_{2} \mathrm{O}_{2}\right)$, peroxyl radical $\left(\mathrm{ROO}^{\bullet}\right)$, and highly reactive hydroxyl radical $\left(\mathrm{OH}^{\bullet}\right)$. Oxidative processes are the most important routes for producing free radicals in living systems. The liver, because of its strategic anatomical action and its large capacity for metabolic conversions, is exposed to many kinds of xenobiotics and therapeutic agents. Due to these facts, efforts to find suitable curatative agents for treatment of liver diseases in natural products of plant and mineral origin are being made [2]. Liver injury induced by $\mathrm{CCl}_{4}$ is the best characterized system of xenobiotics-induced hepatotoxicity in living system. It is a volatile organic chemical and causes liver, kidney and lung damage through free radical mediated process.

Antioxidants are the substances that when present in low concentration significantly delay or reduce the oxidation of the substrate [3]. Antioxidants protect the body from damaging oxidation reactions by reacting with free radicals and other reactive oxygen species; therefore, diseases linked with free radicals can be prevented by antioxidant therapy. The subject has gained an immense importance and current research trends are directed towards finding naturally occurring antioxidants particularly of plant origin [4-6]. Currently, available synthetic antioxidants like butylated hydroxy anisole (BHA), butylated hydroxy toluene (BHT), tertiary butylated hydroquinone, and gallic acid esters have 
been suspected to cause negative health effects. Hence, strong restrictions have been placed on their application, and there is a trend to substitute them with naturally occurring antioxidants. Moreover, these synthetic antioxidants also show low solubility and moderate antioxidant activity [7]. BHA and $\mathrm{BHT}$ are suspected of being responsible for liver toxicity and carcinogenesis $[8,9]$. Traditionally used natural antioxidants from tea, wine, fruits, vegetables, spices, and medicine (e.g., rosemary and sage) are already exploited commercially either as antioxidant additives or a nutritional supplements [10]. Also, many other plant species have been investigated in search of novel antioxidants [11-14], but generally, there is still a demand to find more information concerning the antioxidant potential of plant species. It has been mentioned that the antioxidant activity of plants might be due to their phenolic compounds [15]. Flavonoids are a group of polyphenolic compounds with known properties which include free-radical scavenging, inhibition of hydrolytic and oxidative enzymes, and anti-inflammatory actions [16-18]. The use of traditional medicine is widespread, and plants still present a large source of natural antioxidants that might serve as leads for the development of novel drugs.

The evaluation of plant extracts antioxidant capacity is not an easy task, since many different methods can be used to determine this activity. Substrates, conditions, methods, and concentrations can also affect the estimated activity [19]. Rhizome powder of $P$. hexandrum is locally used as a laxative, to treat intestinal parasites, worms, warts, and tumourous growth on skin [5]. The current study was carried out to examine the antioxidant and protective effects of ethyl acetate rhizome extract of $P$. hexandrum in the rat model of $\mathrm{CCl}_{4}$ induced liver injury.

\section{Materials and Methods}

2.1. Plant Material Collection and Extraction. The rhizome of P. hexandrum was collected from higher reaches of Aharbal, Shopian, J\&K, India, in the month of May and June 2009, identified by the Centre of Plant Taxonomy, Department of Botany, University of Kashmir, and authenticated by Dr. Irshad Ahmad Nawchoo (Department of Botany) and Akhter Hussain Malik (Curator, Centre for Plant Taxonomy, University of Kashmir). A reference specimen has been retained in the herbarium of the Department of Botany at the University of Kashmir under reference number KASHbot/Ku/PH-702-SAG.

The plant material (rhizome) was dried in the shade at $30 \pm 2^{\circ} \mathrm{C}$. The dried rhizome material was ground into a powder using mortar and pestle and passed through a sieve of $0.3 \mathrm{~mm}$ mesh size. The powder obtained was extracted with ethyl acetate using a Soxhlet extractor $\left(60-80^{\circ} \mathrm{C}\right)$. The extract was then concentrated with the help of rotary evaporator under reduced pressure and the solid extract was stored in refrigerator for further use.

2.2. Animals. Adult male albino rats of Wistar strain weighing $200-250 \mathrm{~g}$ used throughout this study were purchased from the Indian Institute of Integrative and Medicine
Jammu (IIIM). The animals had access to food and water ad libitum. The animals were maintained in a controlled environment under standard conditions of temperature and humidity with an alternating $12 \mathrm{hr}$ light and dark cycle. The animals were maintained in accordance with the guidelines prescribed by the National Institute of Nutrition, Indian Council of Medical Research, and the study was approved by the Ethical Committee of the University of Kashmir.

\section{Experimental Methods}

3.1. DPPH Radical Scavenging Activity. The 1, 1- diphenyl-2picryl- hydrazyl (DPPH) assay was performed by using the method of $[4,20]$. Various concentrations of plant extract $(100-1000 \mu \mathrm{g} / \mathrm{mL}$ were added to $1 \mathrm{ml}$ of the $0.004 \%$ methanol solution of DPPH, and the mixture was vortexed vigorously. The tubes were then incubated at room temperature for 30 minutes in dark, and the absorbance was taken at $517 \mathrm{~nm}$. Lower absorbance of the reaction mixture indicates higher free radical scavenging activity. Alpha tocopherol and BHT was taken as known free-radical scavengers. Percentage inhibition activity was calculated by.

$$
\% \text { inhibition }=\left[\frac{\left(\mathrm{A}_{0}-\mathrm{A}_{1}\right)}{\mathrm{A}_{0}}\right] \times 100,
$$

where $A_{0}$ was the absorbance of the control and $A_{1}$ was absorbance in the presence of $P$. hexandrum extract/known antioxidant.

3.2. Assessment of Hydroxyl Radical Scavenging Property. Hydroxyl radical, generated from the $\mathrm{Fe}^{3+}$-Ascorbate- $\mathrm{H}_{2} \mathrm{O}_{2}$ (Fenton reaction), was evaluated by degradation of deoxyribose that produced thiobarbituric acid reactive species (TBARS) [21]. The reaction mixture contained $25 \mathrm{mM}$ deoxyribose, $10 \mathrm{mM}$ Ferric chloride, $100 \mathrm{mM}$ ascorbic acid,

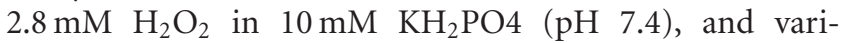
ous concentrations of $P$. hexandrum rhizome ethyl acetate extract. The reaction mixture was incubated at $37^{\circ} \mathrm{C}$ for $1 \mathrm{~h}$. Then, $1 \mathrm{~mL}$ of $1 \%$ thiobarbituric acid and $1 \mathrm{~mL}$ of $3 \%$ trichloroacetic acid was added and mixture heated at $100^{\circ} \mathrm{C}$ for $20 \mathrm{~min}$. The TBARS was measured spectrophotometrically by taking absorbance at $532 \mathrm{~nm}$. The results were expressed as percentage inhibition of deoxyribose oxidation, as determined by.

$$
\text { Percentage inhibition }=\left[\frac{(\mathrm{A}-\mathrm{B})}{\mathrm{A}}\right] \times 100,
$$

where A was the malondialdehyde produced by Fenton reaction treated alone, and $\mathrm{B}$ was the malondialdehyde produced in the presence of $P$. hexandrum extract/known antioxidant.

3.3. Assessment of Superoxide Anion Radical Scavenging Property. Superoxide anion radical generated by the Xanthine/Xanthine oxidase system was spectrophotometrically determined by monitoring the product of nitroblue tetrazolium (NBT) using the method of [22]. A reaction mixture 
containing $1.0 \mathrm{~mL}$ of $0.05 \mathrm{M}$ phosphate buffer ( $\mathrm{pH} 7.4$ ), $0.04 \mathrm{~mL}$ of $0.15 \%$ BSA, $0.04 \mathrm{~mL}$ of $15.0 \mathrm{mM} \mathrm{NBT}$, and various concentrations of (plant extract and known antioxidant) was incubated at $25^{\circ} \mathrm{C}$ for $10 \mathrm{~min}$, and the reaction was then started by adding $0.04 \mathrm{~mL}$ of $1.5 \mathrm{U} / \mathrm{mL}$ Xanthine oxidase and again incubated at $25^{\circ} \mathrm{C}$ for $20 \mathrm{~min}$. The absorbance of the reaction mixture was measured at $560 \mathrm{~nm}$. Decreased absorbance of the reaction mixture indicates increased superoxide anion radical scavenging activity.

The scavenging activity of the plant extract on superoxide anion radical was expressed as

$$
\% \text { inhibition }=\left[\frac{\left(\mathrm{A}_{0}-\mathrm{A}_{1}\right)}{\mathrm{A}_{0}}\right] \times 100,
$$

where $A_{0}$ was the absorbance of the control and $A_{1}$ was absorbance in the presence of $P$. hexandrum extract/known antioxidant.

3.4. Assessment of Hydrogen Peroxide Scavenging Activity. The ability of $P$. hexandrum ethyl acetate extract to scavenge hydrogen peroxide was evaluated according to the method of $[23,24]$. A solution of $\mathrm{H}_{2} \mathrm{O}_{2}$ (2 mmole) was prepared in phosphate buffer ( $\mathrm{pH} 7.5)$. Plant extract $(50-300 \mu \mathrm{g} / \mathrm{mL})$ were added to the hydrogen peroxide solution $(0.6 \mathrm{~mL})$. Absorbance of hydrogen peroxide at $230 \mathrm{~nm}$ was determined after 15 minutes against a blank solution containing phosphate buffer without hydrogen peroxide. BHT was taken as known standard. The scavenging activity of the plant extract on $\mathrm{H}_{2} \mathrm{O}_{2}$ was expressed as

$$
\% \text { scavenged }\left[\mathrm{H}_{2} \mathrm{O}_{2}\right]=\left[\frac{\mathrm{A}_{0}-\mathrm{A}_{1}}{\mathrm{~A}_{0}}\right] \times 100,
$$

where $A_{0}$ is the absorbance of the control and $A_{1}$ is absorbance in the presence of plant extract and known standard.

3.5. Reducing Power. The reducing power of $P$. hexandrum rhizome extract was evaluated according to [25]. Different concentrations of the plant extract were mixed with $2.5 \mathrm{~mL}$ of $0.2 \mathrm{M}$ phosphate buffer ( $\mathrm{pH}$ 6.6) and $2.5 \mathrm{~mL}$ of $1 \%$ potassium hexacyanoferrate II. The mixture was incubated at $50^{\circ} \mathrm{C}$ for 20 minutes, $2.5 \mathrm{~mL}$ of $10 \%$ TCA was added to the mixture and centrifuged at $3000 \mathrm{rpm}$ for 10 minutes. The upper layer of the solution $(2.5 \mathrm{~mL})$ was mixed with distilled water $(2.5 \mathrm{~mL})$ and $\mathrm{FeCl}_{3}(0.5 \mathrm{~mL}, 0.1 \%)$, and the absorbance was measured at $700 \mathrm{~nm}$. BHT (butylated hydroxyl toluene) was taken as the known standard. Increased absorbance of the reaction mixture indicates stronger reducing power.

3.6. Dosage and Treatment. Rats were divided into six groups each containing seven rats. The plant extract was employed at oral doses of 20,30 , and $50 \mathrm{mg} / \mathrm{kg}$-day. The extract was suspended in normal saline such that the final volume of extract at each dose was $1 \mathrm{~mL}$ which was fed to rats by gavage.

Group I: received olive oil vehicle only at $5 \mathrm{~mL} / \mathrm{kg}$ day.
Group II: received $\mathrm{CCl}_{4}$ in olive oil only.

Group III: were administered with vitamin E (50 mg/kg-day).

Group IV: received $20 \mathrm{mg} / \mathrm{kg}$-day extract orally for fifteen days.

Group V: received $30 \mathrm{mg} / \mathrm{kg}$-day extract orally for fifteen days.

Group VI: received $50 \mathrm{mg} / \mathrm{kg}$-day orally for fifteen days.

On the thirteenth day, animals from groups II-VI were injected intraperitoneally with $\mathrm{CCl}_{4}$ in olive oil vehicle at a dosage of $1 \mathrm{~mL} / \mathrm{kg}$ bw. The rats were sacrificed, $48 \mathrm{hr}$ after $\mathrm{CCl}_{4}$ administration, and livers were collected; post mitochondrial supernatant of the liver tissue was prepared as written under preparation of PMS in Section 3.8.

3.7. Blood Collection for Estimation of AST, ALT, and LDH. Before sacrificing the experimental animals, blood was collected from retro-orbital plexus without the use of anticoagulant. The blood was allowed to stand for $10 \mathrm{~min}$ before being centrifuged at 5,000 g for $10 \mathrm{~min}$ to obtain serum for analysis of alanine aminotransferase (ALT), aspartate aminotransferase (AST), and serum lactate dehydrogenase (LDH).

3.7.1. Serum Alanine Aminotransaminase (ALT). ALT was estimated by the method of Reitman and Frankel [26]. Briefly, $0.5 \mathrm{~mL}$ of substrate $(2 \mathrm{mM} \alpha$-ketoglutarate, $0.2 \mathrm{MDL}$-alanine in phosphate buffer $0.1 \mathrm{M} \mathrm{pH} \mathrm{7.4)} \mathrm{was}$ incubated at $37^{\circ} \mathrm{C}$ for 5 minutes. $0.1 \mathrm{~mL}$ of freshly prepared serum will be added to the aliquot and again incubated at $37^{\circ} \mathrm{C}$ for 30 minutes. At the end of incubation $0.5 \mathrm{~mL}$ of 2 , 4-dinitrophenylhydrazine was added, and the aliquot left for 30 minutes at room temperature. $0.5 \mathrm{~mL}$ of $0.4 \mathrm{~N} \mathrm{NaOH}$ was added, and the aliquot is again left for 30 minutes. Absorbance was then recorded at $505 \mathrm{~nm}$ against water blank.

3.7.2. Serum Aspartate Aminotransaminase (AST). AST was again estimated by the method of Reitman and Frankel [26]. The substrate, however, was $2 \mathrm{mM} \alpha$-ketoglutarate, $0.2 \mathrm{M} \mathrm{DL}$-aspartate, and the rest of the procedure was same.

3.7.3. Serum Lactate Dehydrogenase (LDH). LDH was assayed according to the method of King [27]. To $1.0 \mathrm{~mL}$ of buffered substrate (sodium pyruvate $37.5 \mathrm{mM}$ in phosphate buffer $100 \mathrm{mM}, \mathrm{pH} 7.4), 0.1 \mathrm{~mL}$ of freshly prepared serum was added, and the tubes were incubated at $37^{\circ} \mathrm{C}$ for 15 minutes. After adding $0.2 \mathrm{~mL}$ of $\mathrm{NAD}^{+}$solution $(10 \mathrm{mg} / \mathrm{mL}$ in phosphate buffer), the incubation was continued for another 15 minutes. The reaction was arrested by adding $0.1 \mathrm{~mL}$ of 2 , 4-dinitrophenylhydrazine $(0.02 \%$ in concentrated $\mathrm{HCl}$ ), and the tubes were incubated again at $37^{\circ} \mathrm{C}$ for a further period of $15 \mathrm{~min}$, after which $7.0 \mathrm{~mL}$ of $0.4 \mathrm{~N}$ $\mathrm{NaOH}$ was added, and the color developed was measured 
spectrophotometrically at $420 \mathrm{~nm}$ against a blank containing phosphate buffer only.

3.8. Preparation of Post Mitochondrial Supernatant (PMS). Liver tissue was washed in ice-cold $1.15 \% \mathrm{KCl}$ and homogenized in a homogenizing buffer $(50 \mathrm{mM}$ Tris- $\mathrm{HCl}$, $1.15 \% \mathrm{KCl} \mathrm{pH} \mathrm{7.4)} \mathrm{using} \mathrm{a} \mathrm{Teflon} \mathrm{homogenizer.} \mathrm{The}$ homogenate was centrifuged at $9,000 \mathrm{~g}$ for 20 minutes to remove debris. The supernatant was further centrifuged at $15,000 \mathrm{~g}$ for 20 minutes at $4^{\circ} \mathrm{C}$ to get PMS, subsequently used for various biochemical assays. Protein concentration was estimated by the method of Lowry et al. [28].

3.9. Estimation of Lipid Peroxidation (PMS). Lipid peroxidation in liver tissue homogenate was estimated by the formation of thiobarbituric acid reactive substances (TBARS) by the method of [29]. In brief, $0.1 \mathrm{~mL}$ of tissue homogenate (PMS; Tris-HCl buffer, $\mathrm{pH}$ 7.5) was treated with $2 \mathrm{~mL}$ of ( $1: 1: 1$ ratio) TBA-TCA- $\mathrm{HCl}$ reagent $(0.37 \%$ thiobarbituric acid, $0.25 \mathrm{~N} \mathrm{HCl}$, and $15 \%$ TCA), placed in boiling water bath for $15 \mathrm{~min}$, cooled, and centrifuged at room temperature for $10 \mathrm{~min}$. The absorbance of the clear supernatant was measured against reference blank at $535 \mathrm{~nm}$.

3.10. Determination of Total Sulphydryl Groups. The acid soluble sulphydryl groups (nonprotein thiols of which more than $93 \%$ is reduced glutathione (GSH) forms a yellow colored complex with DTNB that shows the absorption maximum at $412 \mathrm{~nm}$. The assay procedure followed was that of [30]. $500 \mu \mathrm{L}$ of homogenate precipitated with $100 \mu \mathrm{L}$ of $25 \%$ TCA was subjected to centrifugation at $300 \mathrm{xg}$ for 10 minutes to settle the precipitate. $100 \mu \mathrm{L}$ of the supernatant was taken in a test tube containing the $2 \mathrm{~mL}$ of $0.6 \mathrm{mM}$ DTNB and $0.9 \mathrm{~mL}$ of $0.2 \mathrm{mM}$ sodium phosphate buffer ( $\mathrm{pH} 7.4$ ). The yellow color obtained was measured at $412 \mathrm{~nm}$ against the reagent blank which contained $100 \mu \mathrm{L}$ of $25 \%$ TCA in place of the supernatant. Sulphydryl content was calculated using the DTNB molar extension coefficient of 13,100.

3.11. Glutathione Peroxidase (GPx). GPx activity was assayed using the method of [31]. The assay mixture consisted of $1.49 \mathrm{~mL}$ of sodium phosphate buffer $(0.1 \mathrm{M} \mathrm{pH} 7.4), 0.1 \mathrm{~mL}$ EDTA $(1 \mathrm{mM}), 0.1 \mathrm{~mL}$ sodium azide $(1 \mathrm{mM}), 0.1 \mathrm{~mL} 1 \mathrm{mM}$ GSH, $0.1 \mathrm{~mL}$ of NADPH $(0.02 \mathrm{mM}), 0.01 \mathrm{~mL}$ of $1 \mathrm{mM} \mathrm{H}_{2} \mathrm{O}_{2}$, and $0.1 \mathrm{~mL}$ PMS in a total volume of $2 \mathrm{~mL}$. Oxidation of NADPH was recorded spectrophotometrically at $340 \mathrm{~nm}$ and the enzyme activity was calculated as nmoles $\mathrm{NADPH}$ oxidized $/ \mathrm{min} / \mathrm{mg}$ of protein, using extinction coefficient of $6.22 \times 10^{3} \mathrm{M}^{-1} \mathrm{~cm}^{-1}$.

3.12. Glutathione Reductase Activity (GR). GR activity was assayed by the method of $[31,32]$. The assay mixture consisted of $1.6 \mathrm{~mL}$ of sodium phosphate buffer $(0.1 \mathrm{M}$ $\mathrm{pH} 7.4), 0.1 \mathrm{~mL}$ EDTA ( $1 \mathrm{mM}), 0.1 \mathrm{~mL} 1 \mathrm{mM}$ oxidized glutathione, $0.1 \mathrm{~mL}$ of NADPH $(0.02 \mathrm{mM}), 0.01 \mathrm{~mL}$ of $1 \mathrm{mM} \mathrm{H}_{2} \mathrm{O}_{2}$, and $0.1 \mathrm{~mL}$ PMS in a total volume of $2 \mathrm{~mL}$.
The enzyme activity measured as absorbance at $340 \mathrm{~nm}$ was calculated as nmoles of NADPH oxidized $/ \mathrm{min} / \mathrm{mg}$ of protein using extinction coefficient of $6.22 \times 10^{3} \mathrm{M}^{-1} \mathrm{~cm}^{-1}$.

3.13. Glutathione-S-Transferase (GST) Activity. GST activity was assayed using the method of [33]. The reaction mixture consisted of $1.67 \mathrm{~mL}$ sodium phosphate buffer $(0.1 \mathrm{M} \mathrm{pH}$ 6.5), $0.2 \mathrm{~mL}$ of $1 \mathrm{mM} \mathrm{GSH}, 0.025 \mathrm{~mL}$ of $1 \mathrm{mM}$ CDNB, and $0.1 \mathrm{~mL}$ of post mitochondrial supernatant in a total volume of $2 \mathrm{~mL}$. The change in absorbance was recorded at $340 \mathrm{~nm}$ and the enzyme activity was calculated as nmoles of CDNB conjugates formed $/ \mathrm{min} / \mathrm{mg}$ protein using extinction coefficient of $9.6 \times 10^{3} \mathrm{M}^{-1} \mathrm{~cm}^{-1}$.

3.14. Superoxide Dismutase Activity (SOD). SOD activity was estimated by Beauchamp and Fridovich [34]. The reaction mixture consisted of $0.5 \mathrm{~mL}$ of hepatic PMS, $1 \mathrm{~mL}$ of $50 \mathrm{mM}$ sodium carbonate, $0.4 \mathrm{~mL}$ of $25 \mu \mathrm{M} \mathrm{NBT}$, and $0.2 \mathrm{~mL}$ of $0.1 \mathrm{mM}$ EDTA. The reaction was initiated by addition of $0.4 \mathrm{~mL}$ of $1 \mathrm{mM}$ hydroxylamine-hydrochloride. The change in absorbance was recorded at $560 \mathrm{~nm}$. The control was simultaneously run without tissue homogenate. Units of SOD activity were expressed as the amount of enzyme required to inhibit the reduction of NBT by $50 \%$.

3.15. Statistical Analysis. The values are expressed as mean \pm standard deviation (SD). The results were evaluated by using the SPSS (version 12.0) and Origen 6 software and evaluated by one-way ANOVA followed by Bonferroni $t$-test. Statistical significance was considered when value of $P$ was <.5.

\section{Results}

In this present study, the antioxidant activity of the ethyl acetate extract of the rhizome of $P$. hexandrum was investigated by using DPPH scavenging assay, hydroxyl assay, $\mathrm{H}_{2} \mathrm{O}_{2}$ assay, superoxide assay, and reducing power. Under in vivo situations, the extract was examined by determining the antioxidant enzymes activities and glutathione levels in the liver tissue homogenate. All the methods have proven the effectiveness of the ethyl acetate extract compared to known antioxidants BHT and $\alpha$-tocopherol.

4.1. DPPH Radical Scavenging Activity. Comparison of the antioxidant activity of the extract and standard antioxidants by DPPH method is shown in Figure 1. The ethyl acetate extract of $P$. hexandrum exhibited dose-dependent inhibition of DPPH activity, and the scavenging activities of the extract and known antioxidants increased with increasing concentration. At higher concentration $(1000 \mu \mathrm{g} / \mathrm{mL})$, the extract and known antioxidants gave the highest percentage activities, that is, $(85.77 \%),(89.77)$ and $(87.7 \%)$, respectively. The percentage inhibition observed is in the following descending order $\alpha$-tocopherol $>$ BHT $>$ ethyl acetate extract. These results suggest that ethyl acetate extract of $P$. hexandrum has a noticeable effect on scavenging of DPPH radical. 


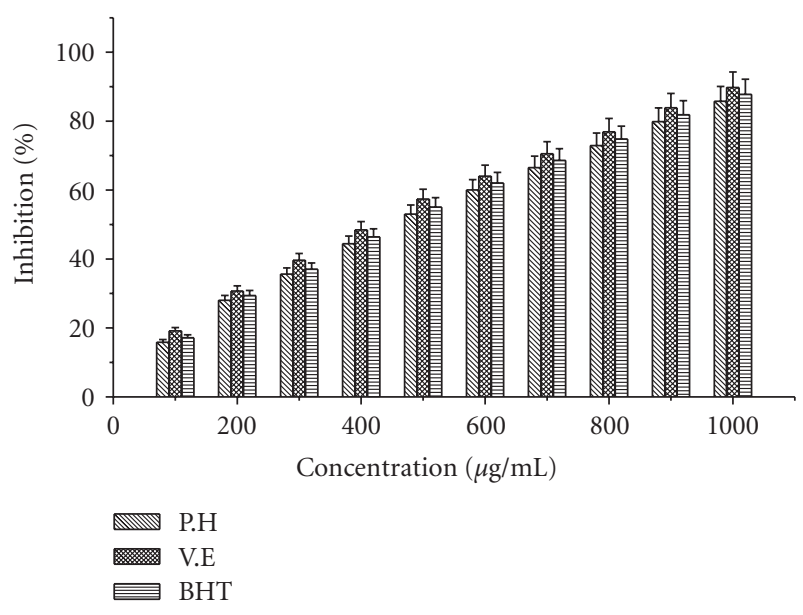

FIGURE 1: Effect of ethyl acetate extract and known antioxidants on DPPH radical scavenging activity. The results represent mean \pm S.D. of 3 separate experiments. Absorbance at $517 \mathrm{~nm}$.

4.2. Hydroxyl Radical Scavenging Activity. The effect of ethyl acetate extract of $P$. hexandrum on the inhibition of hydroxyl radical production was assessed by the iron (II)-dependent deoxyribose damage assay. Figure 2 presents the results of the effects of examined ethyl acetate extract as well as known antioxidants on $\mathrm{OH}^{\bullet}$ radical production. The percentage of hydroxyl radical scavenging activity increased with the increasing concentration of extract and known antioxidants. At a concentration of $300 \mu \mathrm{g} / \mathrm{mL}$, the extract shows the maximum inhibitory effect of about $83.44 \%$ which was comparable to that of $\alpha$-tocopherol ( 88 and $86 \%$ ). The scavenging activity was found in the following order $\alpha$ tocopherol > ethyl acetate extract.

4.3. Superoxide Anion Scavenging Activity. Results of superoxide anion scavenging activity of ethyl acetate extract of rhizome of $P$. hexandrum and known antioxidant BHT are shown in Figure 3. The extract and the standard demonstrate a dose response inhibition on superoxide anion radical. The $\%$ inhibition of superoxide generation by ethyl acetate extract and $\mathrm{BHT}$ was found to be $70.5 \%$ and $78.4 \%$ at a higher concentration of $400 \mu \mathrm{g} / \mathrm{mL}$. the results suggest that ethyl acetate extract has a potent superoxide scavenging effects.

4.4. Hydrogen Peroxide Scavenging Activity. As shown in Figure 4, the ethyl acetate extract of P. hexandrum also demonstrated hydrogen peroxide decomposition activity in a concentration-dependent manner. At the higher concentration $(300 \mu \mathrm{g} / \mathrm{mL})$ of extract and $\mathrm{BHT}$ the $\mathrm{H}_{2} \mathrm{O}_{2}$ scavenging activity was found as $65 \%$ and $70 \%$, respectively. These results showed that ethyl acetate extract had effective $\mathrm{H}_{2} \mathrm{O}_{2}$ scavenging activity.

4.5. Reducing Power Assay. Figure 5 shows the reductive capabilities of ethyl acetate extract of $P$. hexandrum when compared to the standard, BHT. Like the antioxidant activity, the reducing power increased with increasing amount of

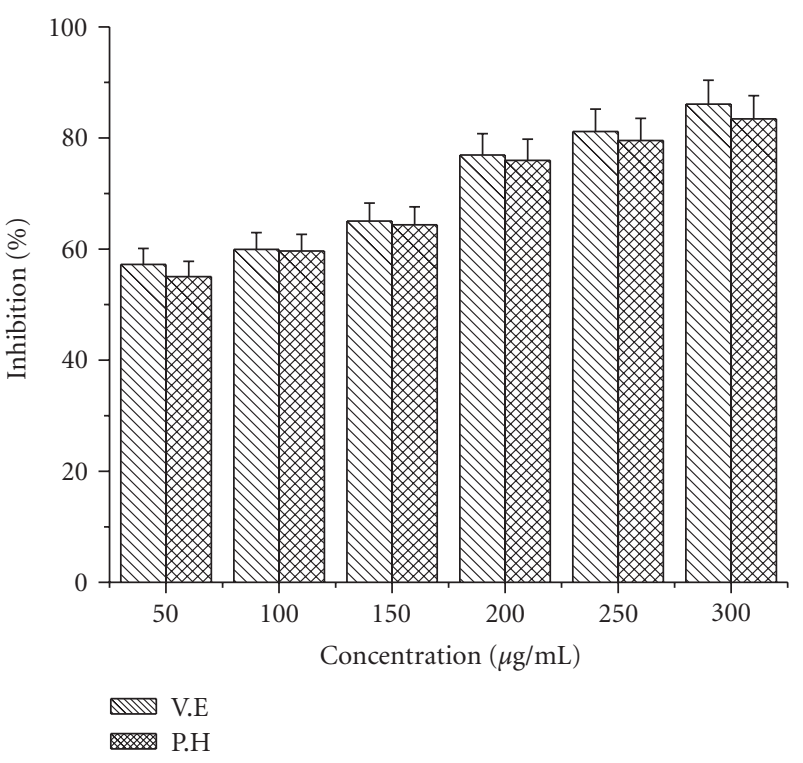

FIGURE 2: Effect of ethyl acetate extract and known antioxidants on hydroxyl radical scavenging activity. The results represent (mean \pm S.D.) of 3 separate experiments. Results are reported as the percentage of the maximum formation of $\mathrm{OH}^{\bullet}$ radical ( $100 \%$ deoxyribose oxidized): in absorbency, $100 \%$ is $1.540 \pm 0.042$ (control). Absorbance at $532 \mathrm{~nm}$.

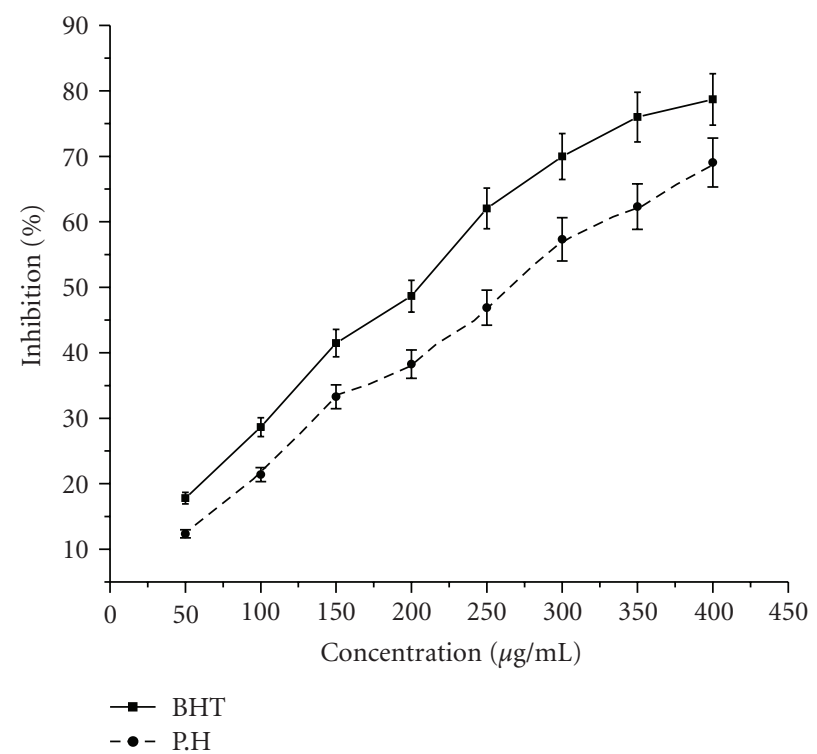

Figure 3: Effect of ethyl acetate extract and known antioxidant BHT on superoxide anion radical scavenging activity. The results represent mean \pm S.D. of 3 separate experiments. Absorbance at $560 \mathrm{~nm}$ (Absorbance of control $=0.883 \pm 0.23$ ).

the extract. For the measurement of the reductive ability, the $\mathrm{Fe}^{3+}-\mathrm{Fe}^{2+}$ transformation was investigated in presence of the extract. Presence of reductants causes the reduction of the $\mathrm{Fe}^{3+} /$ ferricyanide complex to the $\mathrm{Fe}^{2+}$ form. This $\mathrm{Fe}^{2+}$ can be monitored by measuring the formation of Perl's Prussian blue at $700 \mathrm{~nm}$ [35]. At higher concentration of plant extract $(300 \mu \mathrm{g} / \mathrm{mL})$, reducing power value was around 0.53 , 
TABLE 1: Effect of $P$. hexandrum ethyl acetate extract on biochemical parameters in $\mathrm{CCl}_{4}$ induced hepatotoxicity in albino rats.

\begin{tabular}{|c|c|c|c|c|}
\hline Treatment and groups & Dose $(\mathrm{mg} / \mathrm{kg})$ & $\operatorname{AST}(\mathrm{U} / \mathrm{L})$ & $\operatorname{ALT}(\mathrm{U} / \mathrm{L})$ & $\mathrm{LDH}(\mathrm{U} / \mathrm{L})$ \\
\hline 1. Control group (olive oil only) & $5 \mathrm{~mL} / \mathrm{Kg}$ & $37.98 \pm 3.36$ & $28.06 \pm 2.05$ & $89.68 \pm 3.54$ \\
\hline 2. $\mathrm{CCl}_{4}$-treated group & $1 \mathrm{~mL} / \mathrm{Kg}$ & $118.39 \pm 2.83$ & $94.76 \pm 2.78$ & $218.62 \pm 8.20$ \\
\hline 3. $\mathrm{CCl}_{4}$-treated + V.E & $50 \mathrm{mg} / \mathrm{Kg}$ & $67.55 \pm 2.18^{\$ \#}$ & $66.58 \pm 2.54^{\$ \#}$ & $170.88 \pm 5.18^{\$ \#}$ \\
\hline 4. $\mathrm{CCl}_{4}$-treated $+P . H$ extract & $20 \mathrm{mg} / \mathrm{Kg}$ & $100.41 \pm 5.40^{\$ \# @ ~}$ & $79.33 \pm 5.76^{\$ \# @ ~}$ & $193.23 \pm 5.02^{\$ \# @ ~}$ \\
\hline 5. $\mathrm{CCl}_{4}$-treated $+P . H$ extract & $30 \mathrm{mg} / \mathrm{kg}$ & $65.37 \pm 2.0^{\$ \# \mathrm{NS}}$ & $67.22 \pm 1.91^{\$ \# \mathrm{NS}}$ & $178.10 \pm 4.61^{\$ \# b}$ \\
\hline 6. $\mathrm{CCl}_{4}$-treated $+P . H$ extract & $50 \mathrm{mg} / \mathrm{kg}$ & $54.16 \pm 2.96^{\$ \# @ ~}$ & $60.03 \pm 2.73^{\$ \# @ ~}$ & $168.50 \pm 7.20^{\$ \# \mathrm{~b}}$ \\
\hline
\end{tabular}

Each value represents the mean \pm S.D. of 6 animals. ${ }^{\$} ; P<.001$, as compared with normal control group, ${ }^{\#} ; P<.001$ as compared with $\mathrm{CCl}_{4}$ group, ${ }^{\circledR} ; P<.001$ as compared with V.E, NS; nonsignificant as compared with V.E, b; does not test as compared with V.E. The data were presented as means \pm S.D. of six parallel measures and evaluated by one way ANOVA followed by the Bonferroni $t$-test to detect inter group differences. Differences were considered to be statistically significant if $P<.05$.

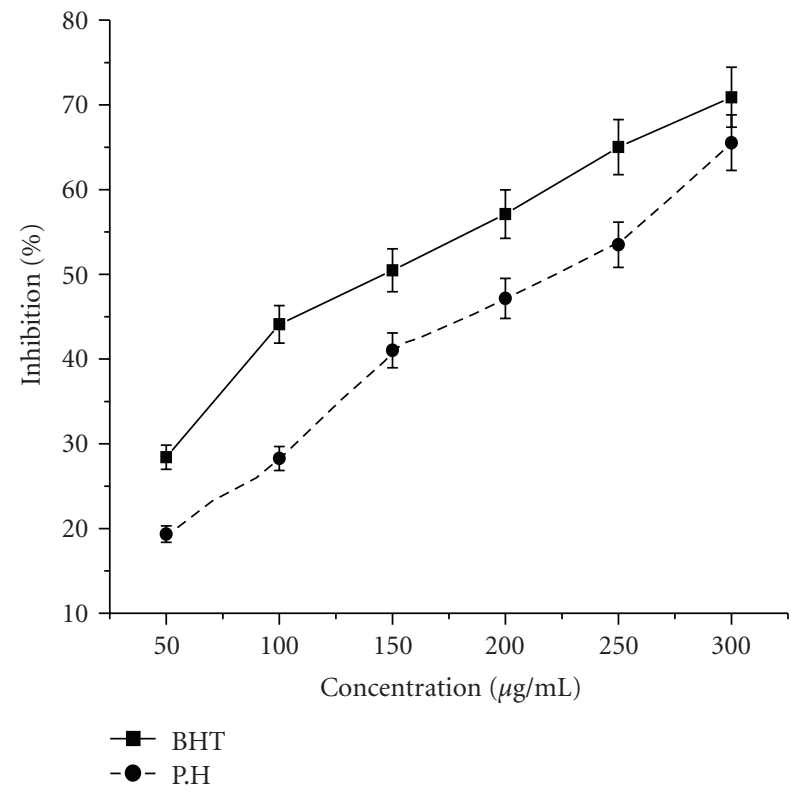

FIGURE 4: Effect of ethyl acetate extract and known antioxidant BHT on hydrogen peroxide radical scavenging activity. The results represent mean \pm S.D. of 3 separate experiments. Absorbance at $230 \mathrm{~nm}$ (Absorbance of control $=0.653 \pm 0.16$ ).

while at the same concentration of BHT, the positive control used in this test, had a reducing power value of 0.65 .

\subsection{Biochemical Parameters.}

4.6.1. Effect of Extract on Hepatic Markers. As depicted in Table 1, administration of $\mathrm{CCl}_{4}$ induced a marked increase in the levels of AST, ALT, and LDH levels as compared to the control group. Group I: (this group was given neither $\mathrm{CCl}_{4}$ nor treatment). They had normal values of AST (37.98), ALT (28.06), and LDH (89.68) units/mL. Group II: (the animals were given only $\mathrm{CCl}_{4}$ ). These rats were found to possess high values of AST (118.39), ALT (94.41), and LDH (218.62) units/mL. Group III: (treated with standard vitamin $\left.\mathrm{E}+\mathrm{CCl}_{4}\right)$. There was a large fall in the values of AST (67.55), ALT (66.58), and LDH (170.88) units/mL. Group IV: (treated with $20 \mathrm{mg} / \mathrm{kg}$ bw ethyl extract $+\mathrm{CCl}_{4}$ ).

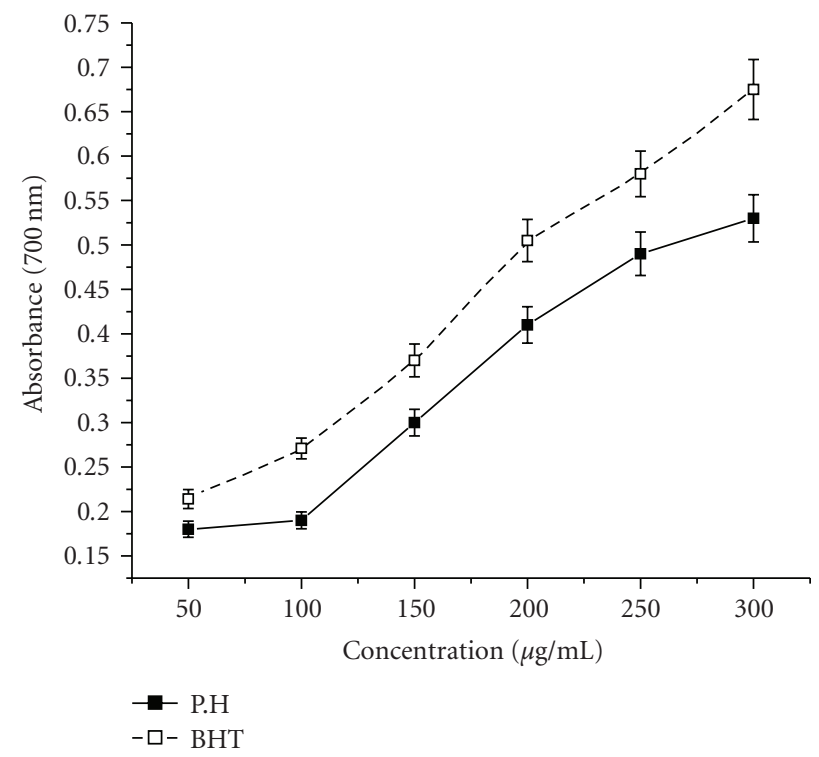

FIGURE 5: Effect of ethyl acetate extract and known antioxidant BHT on reducing power method. The results represent mean \pm S.D. of 3 separate experiments. Absorbance at $700 \mathrm{~nm}$.

There was a slight fall in the values of AST (100.41), ALT (79.33) and $\mathrm{LDH}$ (193.23) units/mL. Group V: (treated $30 \mathrm{mg} / \mathrm{kg}$ bw extract $\left.+\mathrm{CCl}_{4}\right)$. There was a decrease in the values of AST (65.37), ALT (67.22) and LDH (178.10) units/mL Group VI: (treated with $50 \mathrm{mg} / \mathrm{kg}$ bw extract + $\left.\mathrm{CCl}_{4}\right)$. There was a drastic decrease in the values of AST (54.16), ALT (60.03), and LDH (168.10). Group comparison between Group III, Group V and Group VI shows no significant variation in these parameters indicating that ethyl acetate extract has got the same effect as that of the vitamin $\mathrm{E}$ which was used as the positive control in this study.

4.6.2. Effect of Extract on GSH and Antioxidant Enzyme Activities. The findings of present investigation indicate the ethyl acetate extract of $P$. hexandrum and modulate the liver against oxidative stress in a dose-dependent manner without any adverse effect on the animals at the dose levels 
TABLE 2: Effect of treatment of ethyl acetate extract of $P$. hexandrum on glutathione and antioxidant enzymes in $\mathrm{CCl}_{4}$ challenged rats.

\begin{tabular}{|c|c|c|c|c|c|c|}
\hline Parameters & $\begin{array}{l}\text { Group I (olive } \\
\text { oil only) }\end{array}$ & $\begin{array}{l}\text { Group II } \mathrm{CCl}_{4} \\
\text { treated }\end{array}$ & $\begin{array}{l}\text { Group III } \mathrm{CCl}_{4} \\
+ \text { V.E }\end{array}$ & $\begin{array}{l}\text { Group IV } \mathrm{CCl}_{4} \\
+20 \mathrm{mg} / \mathrm{kg} \\
\text { extract }\end{array}$ & $\begin{array}{l}\text { Group } \mathrm{V} \mathrm{CCl}_{4} \\
+30 \mathrm{mg} / \mathrm{kg} \\
\text { extract }\end{array}$ & $\begin{array}{l}\text { Group VI CCl } \\
+50 \mathrm{mg} / \mathrm{kg} \\
\text { extract }\end{array}$ \\
\hline Reduced glutathione (nm/g protein) & $103.94 \pm 6.03$ & $25.14 \pm 2.59^{\$}$ & $87.40 \pm 1.54^{\text {\$\# }}$ & $56.65 \pm 3.40^{\$ \# @ ~}$ & $77.60 \pm 1.85^{\$ \# @ ~}$ & $85.24 \pm 3.87^{\$ \# N S}$ \\
\hline $\begin{array}{l}\text { Glutathione reductase ( } \mu \mathrm{g} \text { GSSG } \\
\text { utilized/minute/mg protein) }\end{array}$ & $32.59 \pm 2.10$ & $2.30 \pm 0.30^{\$}$ & $25.44 \pm 3.06^{\$ \#}$ & $15.36 \pm 1.47^{\$ \# @ ~}$ & $19.65 \pm 1.00^{\$ \# @ ~}$ & $24.55 \pm 1.22^{\$ \# \mathrm{NS}}$ \\
\hline $\begin{array}{l}\text { Glutathione peroxidase ( } \mu \mathrm{g} \text { GSH } \\
\text { utilized/minute/mg protein) }\end{array}$ & $35.48 \pm 2.42$ & $3.20 \pm 0.77^{\$}$ & $28.57 \pm 1.54^{\text {\$\# }}$ & $11.75 \pm 1.30^{\$ \# @ ~}$ & $18.17 \pm 0.31^{\$ \# @ ~}$ & $28.57 \pm 1.54^{\$ \# \mathrm{NS}}$ \\
\hline $\begin{array}{l}\text { Superoxide dismutase (units/mg } \\
\text { protein) }\end{array}$ & $35.41 \pm 0.65$ & $17.16 \pm 1.50^{\$}$ & $27.75 \pm 1.57^{\text {\$\# }}$ & $24.96 \pm 0.54^{\$ \# @ ~}$ & $27.81 \pm 0.94^{\$ \# b}$ & $28.40 \pm 2.47^{\$ \# \mathrm{NS}}$ \\
\hline $\begin{array}{l}\text { Glutathione-S-transferase (nmoles } \\
\text { of CDNB conjugated/min/mg } \\
\text { protein) }\end{array}$ & $15.22 \pm 0.69$ & $4.98 \pm 0.49^{\$}$ & $11.94 \pm 1.13^{\$ \#}$ & $7.60 \pm 1.06^{\$ \# @ ~}$ & $9.95 \pm 0.43^{\$ \# @ ~}$ & $12.70 \pm 0.57^{\$ \# \mathrm{NS}}$ \\
\hline
\end{tabular}

Each value represents the mean \pm S.D. of 6 animals. ${ }^{\$} ; P<.001$, as compared with normal control group, ${ }^{\#} ; P<.001$ as compared with $\mathrm{CCl}_{4}$ group, ${ }^{\circledR} ; P<.001$ as compared with V.E, NS; nonsignificant as compared with V.E, b; does not test as compared with V.E. The data were presented as means \pm S.D. of six parallel measures and evaluated by one way ANOVA followed by the Bonferroni $t$-test to detect inter group differences. Differences were considered to be statistically significant if $P<.05$.

(20, 30, and $50 \mathrm{mg} / \mathrm{kg}$ body weight/day for 15 days, respectively). Table 2 shows oxidative stress by $\mathrm{CCl}_{4}$ caused significant alterations in hepatic antioxidant defense system like GSH, GR, GPx, SOD, and GST contents in comparison to the normal controls.

4.6.3. Effect of Extract on Glutathione Reductase (GR). Glutathione reductase (GR) activities in the liver homogenate of rats for all experimental groups are shown in the Table 2. The GR activity in the liver tissue homogenates of $\mathrm{CCl}_{4}$-treated rats was considerably lower than that of normal control rats $(32.59 \pm 2.10)$. In the pretreated group, which got the ethyl acetate extract for 15 days prior to $\mathrm{CCl}_{4}$, GR activity was significantly higher compared to the $\mathrm{CCl}_{4}$-treated group $(2.30 \pm 0.30)$. The GR activity in group III rats receiving vitamin E $(25.44 \pm 3.06)$ was found comparable to the group VI rats receiving the high concentration of plant extract $(50 \mathrm{mg} / \mathrm{kg}$ bw/day) $(24.55 \pm 1.22)$. Rats of groups IV and $\mathrm{V}$ receiving the oral dose of 20 and $30 \mathrm{mg} / \mathrm{kg}$ bw/day plant extract increases the GR activity to $15.36 \pm 1.47$ and $19.65 \pm 1$ from $2.30 \pm 0.3$ (group II) Table 2.

4.6.4. Effect of Extract on Glutathione Peroxidase $\left(G P_{X}\right)$. $\mathrm{CCl}_{4}$ treatment caused a significant decrease in the level of glutathione peroxidase $(\mathrm{GPx})$ activity in liver tissue when compared with control group (Table 2). The treatment of $P$. hexandrum ethyl acetate extract at the doses of 20,30, and $50 \mathrm{mg} / \mathrm{kg} \mathrm{bw} /$ day resulted in a dose-dependent increase of $\mathrm{GP}_{\mathrm{X}}$ when compared to $\mathrm{CCl}_{4}$-treated rats. The liver of vitamin E-treated animals also showed a significant increase in $\mathrm{GP}_{\mathrm{X}}$ activity compared to $\mathrm{CCl}_{4}$-treated rats.

4.6.5. Effect of Extract on Superoxide Dismutase Activity (SOD). The activities of SOD in the tissue homogenates of all experimental rats are shown in Table 2. In the liver homogenate, $\mathrm{CCl}_{4}$-treatment caused reduction of the SOD activity (17.16 units/mg protein) compared to the normal control group (35.41 units/mg protein). Enhancement of
SOD activity was observed in case of 15 days treatment of ethyl acetate extract at the dose level of 20,30 , and $50 \mathrm{mg} / \mathrm{kg}$ body weight/day prior to the $\mathrm{CCl}_{4}$ administration, and the activity was found to be increased in a dose-dependent manner. Similar results were obtained with the antioxidant vitamin E.

4.6.6. Effect of Extract on Glutathione-S-Transferase Activity (GST). Table 2 showed significant decreased in hepatic glutathione-S-transferase (GST) activity upon $\mathrm{CCl}_{4}$ administration by $4.98 \pm 0.49$ as compared to the control group $15.22 \pm 0.69$. A significant increase in GST activity was observed in the group of rats treated with ethyl acetate extract of $P$. hexandrum at the oral dose of 20,30 , and $50 \mathrm{mg} / \mathrm{kg}$ bw/day by 7.60, 9.95 and 12.70, respectively, as compared to $\mathrm{CCl}_{4}$-treated group. In group III, the rats continuously treated with vitamin E (50 mg/kg bw/day) increased the GST activity significantly by 11.94 as compared to $\mathrm{CCl}_{4}$-treated group.

4.6.7. Effect of Extract on Glutathione Levels (GSH). Effect of ethyl acetate extract of $P$. hexandrum on GSH level for all experimental groups is shown in Table 2. $\mathrm{CCl}_{4}$ treatment caused significant decrease of GSH level in liver tissue homogenates compared to the normal group. When rats were treated by $\mathrm{CCl}_{4}, \mathrm{GSH}$ decreased from $103.94 \pm 6.03 \mathrm{mg} / \mathrm{g}$ protein (control group) to $25.14 \pm$ $2.59 \mathrm{mg} / \mathrm{g}$ protein $\left(\mathrm{CCl}_{4}\right.$-treated group). Pretreatment of ethyl acetate extract for 15 days at the oral doses of 20, 30, and $50 \mathrm{mg} / \mathrm{kg}$ bw/day followed by 2 days of $\mathrm{CCl}_{4}$ treatment enhance the level of GSH to $56.65,77.60$, and $85.24 \mathrm{mg} / \mathrm{g}$ protein. Similar results were obtained with vitamin E.

4.6.8. Effect of Extract on Lipid Peroxidation (LP). The localization of radical formation resulting in lipid peroxidation, measured as MDA in rat liver homogenate 
is shown in Figure 6. From our results, it was found that $P$. hexandrum ethyl acetate extract could significantly decrease the formation of Malondialdehyde (MDA) in $\mathrm{CCl}_{4}$ treated rats. After $\mathrm{CCl}_{4}$ administration, the liver MDA level significantly increased from $2.87 \pm 0.36 \mathrm{nmol} / \mathrm{mg}$ protein (control group) to $10.16 \pm 0.95 \mathrm{nmol} / \mathrm{mg}$ protein. However, oral administration of $P$. hexandrum extract at the concentration of 20,30 , and $50 \mathrm{mg} / \mathrm{kg}$ bw/day, the liver MDA level decreased to $7.27 \pm 0.26,4.80 \pm 0.32$, and $3.73 \pm 0.38$, respectively. At the same time, the effect of vitamin $\mathrm{E}(50 \mathrm{mg} / \mathrm{kg} /$ day $)$ on $\mathrm{MDA}$ levels in $\mathrm{CCl}_{4}$ treated rats was found to be reduced to $3.81 \mathrm{nmol} / \mathrm{mg}$ protein.

\section{Discussion}

Free radical oxidative stress has been implicated in the pathogenesis of a wide variety of clinical disorders, resulting usually from deficient natural antioxidant defenses. Potential antioxidant therapy, therefore, should include either natural free-radical scavenging antioxidant enzymes or agents which are capable of augmenting the activity of these enzymes. Reactive oxygen species (ROS) has received considerable attention in the recent past because of its role in several pathological conditions including cancer, diabetes, arthritis, aging, and atherosclerosis. $\mathrm{ROS}$ produced in vivo $\mathrm{O}_{2}{ }^{-}$, hydrogen peroxide $\left(\mathrm{H}_{2} \mathrm{O}_{2}\right)$, and hypochlorous acid $(\mathrm{HOCl})$, and $\mathrm{H}_{2} \mathrm{O}_{2}$ can interact in the presence of transition metal ions to yield a highly reactive oxidizing species, the hydroxy radical [36]. If human disease is believed to be due to the imbalance between oxidative stress and antioxidative defense, it is possible to limit oxidative tissue damage and hence prevent disease progression by antioxidant defense supplements.

In our study, antioxidant effects of rhizome ethyl acetate extract of $P$. hexandrum were measured through a variety of biological parameters and compared with some of the known antioxidants. Because of the complex nature of phytochemicals, the antioxidant activities of plant extracts cannot be evaluated by a single method. Therefore, commonly accepted assays, including enzymatic and nonenzymatic methods under in vitro and in vivo conditions were employed to evaluate the total antioxidant potential of plant extracts.

$\mathrm{DPPH}$ is characterized as stable free radical by virtue of the delocalization of the spare electron, where the molecule as a whole, so that the molecule do not dimerise, as would be the case with most other free radicals. The delocalization gives rise to the deep violet colour, characterized by an absorption band $(517 \mathrm{~nm})$. When a solution of DPPH is mixed with a substance of $\mathrm{H}$ donor, it gets reduced into nonradical state [37]. Hence, the ethyl acetate extract of $P$. hexandrum exhibited a significant dose-dependant inhibition of DPPH activity. Similar results were reported by [38], while investigating the DPPH radical scavenging activity of wormwood (Artemisia absinthium $\mathrm{L}$ ).

Similarly, results were also reported by [37] that extracts of Pterocarpus santalinus exhibited significant DPPH radical scavenging activity. The observed scavenging effect of

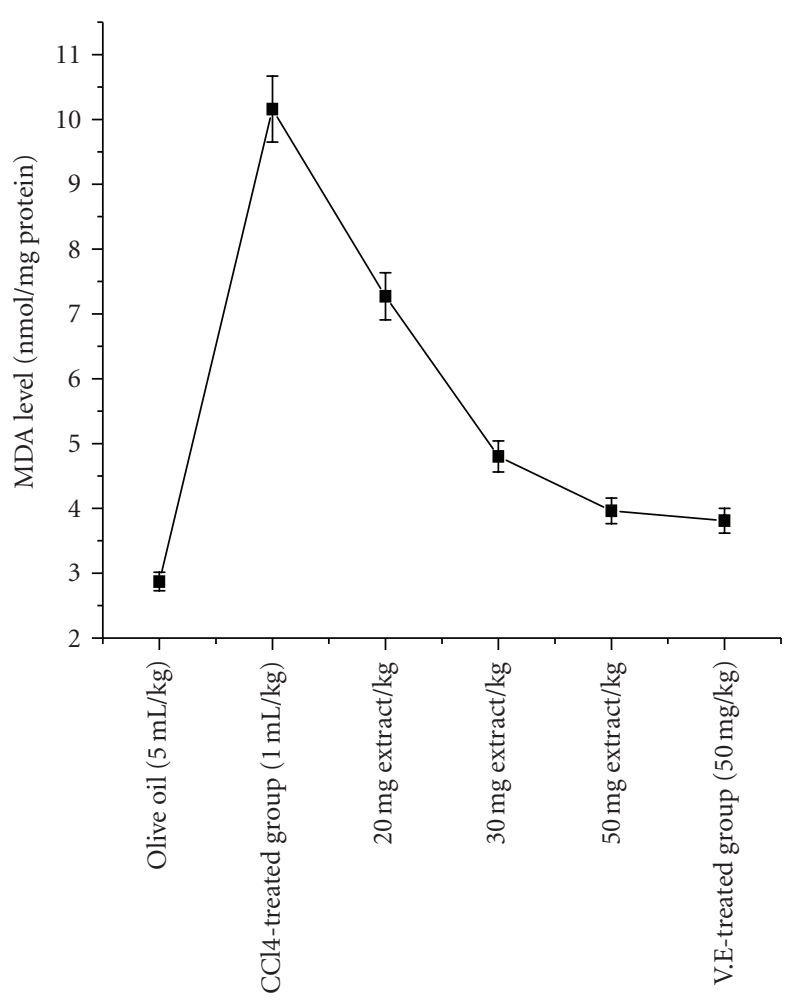

FIgURe 6: Effect of Podophyllum hexandrum ethyl acetate extract and vitamin $\mathrm{E}$ on liver homogenate lipid peroxidation of $\mathrm{CCl}_{4}{ }^{-}$ treated rats in vivo. The results represent mean \pm S.D. of 6 animals in each group and evaluated by one-way ANOVA followed by the Bonferroni $t$-test. Differences were considered to be statistically significant if $P<.05$.

$P$. hexandrum ethyl acetate extract and standards on the DPPH radical decreases in the following order: $\alpha$ tocopherol $>$ BHT $>$ Ethyl acetate and it was $89.77 \%, 87.77 \%$, and $85.77 \%$ at concentration of $1000 \mu \mathrm{g} / \mathrm{mL}$, respectively.

Our results are in tune with earlier investigations that the methanol extracts of exhibited significant DPPH radical inhibition

The reducing ability of a compound generally depends on the presence of reductants [39] which have been exhibited antioxidative potential by breaking the free-radical chain, donating a hydrogen atom [40]. Presence of reducers causes the conversion of the $\mathrm{Fe}^{3+} /$ ferricyanide complex used in this method to the ferrous form. By measuring the formation of Perl's Prussian blue at $700 \mathrm{~nm}$, it is possible to determine the $\mathrm{Fe}^{2+}$ concentration. Our results suggest that polyphenolic components within the ethyl acetate extract of $P$. hexandrum play an important role in scavenging of free radicals, and the scavenging activity is increased with the increasing concentration of the plantextract. At the higher concentration $(300 \mu \mathrm{g} / \mathrm{mL})$, the reducing power of ethyl acetate extract of $P$. hexandrum and the known antioxidant BHT was $0.53 \pm$ 0.005 and $0.675 \pm 0.05$, respectively. Our results showed that $P$. hexandrum rhizome ethyl acetate extract is an electron donor and could react with free radicals, convert them to more stable products, and terminate radical chain reaction. 
Similar results were reported by Noriham et al. [41], who demonstrated antioxidative activity on Pimpinella anisum seed extracts and different types of Malaysian plants, and [42] showed that $P$. fascisepala leaf extract is an electron donor and could react with free radicals and terminate radical chain reaction.

Highly reactive $\mathrm{OH}^{\bullet}$ radicals are responsible for the oxidative damage of DNA, lipids, and proteins [43]. Formation of a highly reactive tissue-damaging species like hydroxyl radical is caused by the interaction of iron ions with hydrogen peroxide in biological system [44]. The rhizome of $P$. hexandrum ethyl acetate extract exhibited hydroxyl radical scavenging activity in a dose-dependent manner. At a concentration of $300 \mu \mathrm{g} / \mathrm{mL}$, the extract shows a maximum inhibitory effect of about $83 \%$, which was comparable to the known antioxidant BHT $(86 \%)$. These results show that ethyl acetate extract of $P$. hexandrum rhizome can act as effective antioxidants by reacting with free radicals.

Superoxide anion, which is a reduced form of molecular oxygen, has been implicated in the initiating oxidation reactions associated with aging [45]. Also, it has been implicated in several pathophysiological processes, due to its transformation into more reactive species such as hydroxyl radical that initiate lipid peroxidation. Superoxide has also been observed to directly initiate lipid peroxidation [46]. In the Xanthine/Xanthine oxidase system, superoxide anion derived from dissolved oxygen reduces NBT. Antioxidants are able to inhibit the blue NBT formation [47]. The superoxide radical scavenging activity of $P$. hexandrum ethyl acetate extract, and the standard BHT increased in a dosedependent manner. At the concentration of $300 \mu \mathrm{g} / \mathrm{mL}$, the percentage inhibition on superoxide radical observed was 69.05 and $78.70 \%$, respectively. Similar results reported by [48] that different extracts from Croton celtidifolius Baill (Euphorbiaceae) showed in vitro antioxidant properties through the superoxide scavenger capacity method by the nitro blue tetrazolium (NBT) reduction assay.

The measurement of $\mathrm{H}_{2} \mathrm{O}_{2}$-scavenging activity is one of the useful methods of determining the ability of antioxidants to decrease the level of pro-oxidants such as $\mathrm{H}_{2} \mathrm{O}_{2}$ [49]. It can cross membranes and may slowly oxidize a number of compounds. Hydrogen peroxide itself is not very reactive, but sometimes, it can be toxic to cells because of rise in the hydroxyl radicals in the cells [50]. In our study, the $\mathrm{H}_{2} \mathrm{O}_{2}$ scavenging activity of $P$. hexandrum ethyl acetate extract and the standard BHT increased in a dose-dependent manner. At the concentration of $300 \mu \mathrm{g} / \mathrm{mL}$, the percentage inhibition on $\mathrm{H}_{2} \mathrm{O}_{2}$ was observed $65.54 \%$ and $70.91 \%$, respectively. This ability to scavenge hydrogen peroxide could be an efficient assessment method to evaluate antioxidant property of extract of $P$. hexandrum.

In accordance with the results of the antioxidant effects of the extract of $P$. hexandrum rhizome obtained in in vitro assays, examinations of the in vivo activity of ethyl acetate extract of $P$. hexandrum was also conducted.

$\mathrm{CCl}_{4}$-induced hepatic injuries are commonly used animal models for the screening of hepatoprotective plant extracts and the magnitude of hepatic damage is assessed by measuring the level of released cytosolic transaminases including ALT and AST in circulation [51]. It is generally thought that $\mathrm{CCl}_{4}$ toxicity is due to reactive free radical $\left(\mathrm{CCl}_{3}{ }^{\circ}\right)$, which is generated by its reductive metabolism by hepatic cytochrome $\mathrm{P} 450$. The reactive intermediate is believed to cause lipid peroxidation and breakdown of cellular membranes [52]. This present study evaluated the hepatoprotective effects of $P$. hexandrum ethyl acetate extract on $\mathrm{CCl}_{4}$-induced liver toxicity. Acute administration of $\mathrm{CCl}_{4}$ produced a marked elevation of the serum levels of AST, ALT, and LDH in (Group II) treated animals when compared with that of the control group (Group I). Treatment with $P$. hexandrum ethyl acetate extract at a dose of 20,30, and $50 \mathrm{mg} / \mathrm{kg} /$ day significantly reduced the elevated levels of the enzymes (Table 1). Similarly reported by [53] that the ethyl acetate extract of Cadaba farinosa exerts protective action by decreasing $\mathrm{CCl}_{4}$-derived free radicals and significantly inhibit the elevated level of serum enzyme activities.

Decreased serum levels of AST, ALT and LDH by the plant extract is an indication of stabilization of plasma membrane as well as repair of hepatic tissue damage caused by $\mathrm{CCl}_{4}$. The above changes can be considered as an expression of the functional improvement of hepatocytes, which may be caused by an accelerated regeneration of parenchyma cells.

The body has an effective mechanism to prevent and neutralize the free radical induced damage. This is accomplished by a set of endogenous antioxidant enzymes, such as SOD, CAT, GPX, GST, and GRD. When the balance between ROS production and antioxidant defenses is lost, "oxidative stress" results, which through a series of events deregulates the cellular functions leading to various pathological conditions [54] Any compound, natural or synthetic, with antioxidant properties might contribute towards the partial or total alleviation of this type of damage. In the present study, elevated level of TBARS in $\mathrm{CCl}_{4}$-treated rats indicates excessive formation of free radicals and activation of LP system resulting in hepatic damage. TBARS produced as byproducts of LP that occurs in hydrophobic core of biomembranes [55]. The significant decline in the concentration of these constituents in the liver tissue of $\mathrm{CCl}_{4}$ and ethyl extract administered rats indicates antilipid peroxidative effect of $P$. hexandrum.

GSH is a major nonprotein thiol in living organisms which plays a central role in coordinating the body's antioxidant defense processes. Perturbation of GSH status of a biological system has been reported to lead to serious consequences [54]. Decline in GSH content in the liver of $\mathrm{CCl}_{4}$-intoxicated rats, and its dose dependent increased level with the administration of extract reveal antioxidant effect of $P$. hexandrum. SOD, GR, GST, and $\mathrm{GP}_{X}$ constitute a mutually supportive team of defense against ROS. SOD is a metalloprotein and is the first enzyme involved in the antioxidant defense by lowering the steady-state level of $\mathrm{O}_{2}{ }^{-}$. $\mathrm{GP}_{\mathrm{X}}$ is a selenoenzyme two third of which (in liver) is present in the cytosol and one third in the mitochondria. It catalyses the reaction of hydroperoxides with reduced glutathione to form glutathione disulphide (GSSG) and the reduction product of the hydroperoxide. In our study, decline in the activities of these enzymes in $\mathrm{CCl}_{4}$-administered 
rats revealed that $\mathrm{LP}$ and oxidative stress elicited by $\mathrm{CCl}_{4}$ intoxication have been nullified due to the effect of $P$. hexandrum ethyl acetate extract. Similar results were reported by [56] who investigated hepatoprotective and antioxidant activity of Boehmeria nivea. GTS plays an essential role in liver by eliminating toxic compounds by conjugating them with glutathione. GR is concerned with the maintenance of cellular level of GSH (especially in the reduced state) by effecting fast reduction of oxidized glutathione to reduced form. In our study, the liver tissues of $\mathrm{CCl}_{4}$-administered rats, activities of GTS and GR were significantly decreased compared with control group. However, pretreatment with ethyl acetate extract of $P$. hexandrum, the activity of these enzymes significantly increased, thus unearthing the antioxidant effect of $P$. hexandrum. Similar results were reported by [57] showed that Nigella sativa L and Urtica dioica L increase the antioxidant defense system activity in experimentally $\mathrm{CCl}_{4}$-treated rats.

\section{Conclusion}

In conclusion, it is well known that the hepatoprotective effect has a good correlation with the antioxidant activities $[58,59]$. In our previous studies, methanolic and $70 \%$ ethanolic rhizome extracts of $P$. hexandrum have been demonstrated to possess excellent antioxidant activities by various in vitro and in vivo assays $[5,6,60]$. In the current study, the encouraging results of the ethyl acetate extract of $P$. hexandrum with the various in vitro antioxidant tests proved that the plant possess components with reducing activity has hydrogen-donating ability as well as effectiveness as scavengers of hydroxyl radical, hydrogen peroxide radical, and superoxide free radicals. Current study also demonstrates that ethyl acetate extract could reduce $\mathrm{CCl}_{4}$ induced toxicity, particularly hepatotoxicity, by inhibiting lipid peroxidation, suppressing alanine aminotransferase (ALT), aspartate aminotransferase (AST) activities, and lactate dehydrogenase activity (LDH), and increasing antioxidant enzyme activity. Therefore, ethyl acetate extract of $P$. hexandrum can be proposed to protect the liver against $\mathrm{CCl}_{4}$ induced oxidative damage in rats, and the hepatoprotective effect might be correlated with its antioxidant and free radical scavenger effects. The studies are in progress to isolate and purify the active principle involved in antioxidant activities of this plant. Further research is needed to study the mechanisms of activity of the active compounds responsible for antihepatotoxic activity.

\section{References}

[1] J. M. C. Gutteridge, "Free radicals in disease processes: a compilation of cause and consequence," Free Radical Research Communications, vol. 19, no. 3, pp. 141-158, 1993.

[2] O. I. Aruoma, "Free radicals, oxidative stress, and antioxidants in human health and disease," Journal of the American Oil Chemists' Society, vol. 75, no. 2, pp. 199-212, 1998.

[3] B. Halliwell, "The antioxidant paradox," The Lancet, vol. 355, no. 9210, pp. 1179-1180, 2000.
[4] T. Ak and I. Gülçin, "Antioxidant and radical scavenging properties of curcumin," Chemico-Biological Interactions, vol. 174, no. 1, pp. 27-37, 2008.

[5] S. A. Ganie, M. A. Zaragar, A. Masood, and E. Haq, "In vitro and in vivo evaluation of free radical scavenging potential of ethanolic extract of Podophyllum hexandrum," African Journal of Biochemistry Research, vol. 4, no. 8, pp. 196-203, 2010.

[6] S. A. Ganie, E. Haq, A. Masood, and M. A. Zargar, "Amelioration of carbon tetrachloride induced oxidative stress in kidney and lung tissues by ethanolic rhizome extract of Podophyllum hexandrum in Wistar rats," Journal of Medicinal Plant Research, vol. 4, no. 16, pp. 1673-1677, 2010.

[7] A. L. Branen, "Toxicology and biochemistry of butylated hydroxyanisole and butylated hydroxytoluene," Journal of the American Oil Chemists' Society, vol. 52, no. 2, pp. 59-63, 1975.

[8] H. C. Grice, "Safety evaluation of butylated hydroxytoluene (BHT) in the liver, lung and gastrointestinal tract," Food and Chemical Toxicology, vol. 24, pp. 1127-1130, 1986.

[9] H. P. Wichi, "Enhanced tumor development by butylated hydroxyanisole (BHA) from the prospective of effect on forestomach and oesophageal squamous epithelium," Food and Chemical Toxicology, vol. 26, no. 8, pp. 717-723, 1988.

[10] P. Schuler, "Natural antioxidants exploited commercially," in Food Antioxidants, B. J. F. Hudson, Ed., pp. 99-170, Elsevier, London, UK, 1990.

[11] D. Mantle, F. Eddeb, and A. T. Pickering, "Comparison of relative antioxidant activities of British medicinal plant species in vitro," Journal of Ethnopharmacology, vol. 72, no. 1-2, pp. 47-51, 2000.

[12] I. I. Koleva, T. A. Van Beek, J. P. H. Linssen, A. de Groot, and L. N. Evstatieva, "Screening of plant extracts for antioxidant activity: a comparative study on three testing methods," Phytochemical Analysis, vol. 13, no. 1, pp. 8-17, 2002.

[13] J. M. Oke and M. O. Hamburger, "Screening of some Nigerian medicinal plants for antioxidant activity using 2, 2diphenyl-picryl-hydrazyl radical," African Journal of Biomedical Research, vol. 5, pp. 77-79, 2002.

[14] I. Parejo, F. Viladomat, J. Bastida et al., "Investigation of Bolivian plant extracts for their radical scavenging activity and antioxidant activity," Life Sciences, vol. 73, no. 13, pp. 1667$1681,2003$.

[15] N. C. Cook and S. Samman, "Flavonoids-chemistry, metabolism, cardioprotective effects, and dietary sources," Journal of Nutritional Biochemistry, vol. 7, no. 2, pp. 66-76, 1996.

[16] S. A. Frautschy, W. Hu, P. Kim et al., "Phenolic antiinflammatory antioxidant reversal of $\mathrm{A} \beta$-induced cognitive deficits and neuropathology," Neurobiology of Aging, vol. 22, no. 6, pp. 993-1005, 2001.

[17] L. Wang, YI. C. Tu, T. W. Lian, J. T. Hung, J. H. Yen, and M. J. $\mathrm{Wu}$, "Distinctive antioxidant and antiinflammatory effects of flavonols," Journal of Agricultural and Food Chemistry, vol. 54, no. 26, pp. 9798-9804, 2006.

[18] M. Clavin, S. Gorzalczany, A. Macho et al., "Antiinflammatory activity of flavonoids from Eupatorium arnottianum," Journal of Ethnopharmacology, vol. 112, no. 3, pp. 585-589, 2007.

[19] E. N. Frankel and A. S. Meyer, "The problems of using onedimensional methods to evaluate multifunctional food and biological antioxidants," Journal of the Science of Food and Agriculture, vol. 80, no. 13, pp. 1925-1941, 2000.

[20] A. Braca, N. De Tommasi, L. Di Bari, C. Pizza, M. Politi, and I. 
Morelli, "Antioxidant principles from Bauhinia tarapotensis," Journal of Natural Products, vol. 64, no. 7, pp. 892-895, 2001.

[21] B. Halliwell, J. M. C. Gutteridge, and O. I. Aruoma, "The deoxyribose method: a simple 'test-tube' assay for determination of rate constants for reactions of hydroxyl radicals," Analytical Biochemistry, vol. 165, no. 1, pp. 215-219, 1987.

[22] C.-H. Jung, H.-M. Seog, I.-W. Choi, M.-W. Park, and H.Y. Cho, "Antioxidant properties of various solvent extracts from wild ginseng leaves," LWT_Food Science and Technology, vol. 39, no. 3, pp. 266-274, 2006.

[23] R. J. Ruch, S. J. Cheng, and J. E. Klaunig, "Prevention of cytotoxicity and inhibition of intercellular communication by antioxidant catechins isolated from Chinese green tea," Carcinogenesis, vol. 10, no. 6, pp. 1003-1008, 1989.

[24] O. Talaz, I. Gülçin, S. Göksu, and N. Saracoglu, "Antioxidant activity of 5,10-dihydroindeno[1,2-b]indoles containing substituents on dihydroindeno part," Bioorganic and Medicinal Chemistry, vol. 17, no. 18, pp. 6583-6589, 2009.

[25] M. Oyaizu, "Studies on products of browning reaction prepared from glucosamine," Japanese Journal of Nutrition, vol. 44, pp. 307-315, 1986.

[26] S. Reitman and S. Frankel, "A colorimetric method for the determination of serum glutamic oxalacetic and glutamic pyruvic transaminases," American Journal of Clinical Pathology, vol. 28, no. 1, pp. 56-63, 1957.

[27] J. King, "The dehydrogenase of oxidoreductase-Lactate dehydrogenase," in Practical Clinical Enzymology, J. C. King, Ed., pp. 83-93, Van Nostrand, London, UK, 1965.

[28] O. H. Lowry, N. J. Rosenbrough, A. L. Farr, and R. J. Randall, "Protein measurement with the Folin phenol reagent," The Journal of biological chemistry, vol. 193, no. 1, pp. 265-275, 1951.

[29] W. G. Nichans and D. Samuelson, "Formation of malondialdehyde from phospholipid arachidonate during microsomal lipid peroxidation," European Journal of Biochemistry, vol. 6, p. 126, 1968.

[30] M. S. Moron, J. W. Depierre, and B. Mannervik, "Levels of glutathione, glutathione reductase and glutathione Stransferase activities in rat lung and liver," Biochimica et Biophysica Acta, vol. 582, no. 1, pp. 67-78, 1979.

[31] N. Sharma, P. Trikha, M. Athar, and S. Raisuddin, "Inhibition of benzo[a]pyrene- and cyclophoshamide-induced mutagenicity by Cinnamomum cassia," Mutation Research, vol. 480-481, pp. 179-188, 2001.

[32] M. Şentürk, I. Gülçin, M. Çiftci, and O. I. Küfrevioğlu, "Dantrolene inhibits human erythrocyte glutathione reductase," Biological and Pharmaceutical Bulletin, vol. 31, no. 11, pp. 2036-2039, 2008.

[33] R. Haque, B. Bin-Hafeez, S. Parvez et al., "Aqueous extract of walnut (Juglans regia L.) protects mice against cyclophosphamide-induced biochemical toxicity," Human and Experimental Toxicology, vol. 22, no. 9, pp. 473-480, 2003.

[34] C. Beauchamp and I. Fridovich, "Superoxide dismutase: improved assays and an assay applicable to acrylamide gels," Analytical Biochemistry, vol. 44, no. 1, pp. 276-287, 1971.

[35] I. Gülçin, "Antioxidant properties of resveratrol: a structureactivity insight," Innovative Food Science and Emerging Technologies, vol. 11, no. 1, pp. 210-218, 2010.

[36] H. Shinmoto, S. Dosako, and I. Nakajima, "Antioxidant activity of bovine lactoferrineon iron/ascorbate induced lipid peroxidation," Bioscience, Biotechnology, and Biochemistry, vol. 56, pp. 2079-2080, 1992.

[37] S. Arokiyaraj, S. Martin, K. Perinbam, P. Marie Arockianathan, and V. Beatrice, "Free radical scavenging activity and HPTLC finger print of Pterocarpus santalinus L, an in vitro study," Indian Journal of Science and Technology, vol. 7, no. 1, pp. 1-3, 2008.

[38] T. Yokozawa, C. P. Chen, E. Dong, T. Tanaka, G. I. Nonaka, and I. Nishioka, "Study on the inhibitory effect of tannins and flavonoids against the 1,1-diphenyl-2-picrylhydrazyl radical," Biochemical Pharmacology, vol. 56, no. 2, pp. 213-222, 1998.

[39] P. D. Duh, Y. Y. Tu, and G. C. Yen, "Antioxidant activity of water extract of Harng Jyur (Chrysanthemum morifolium Ramat)," Lebensmittel-Wissenschaft und-Technologie, vol. 32, no. 5, pp. 269-277, 1999.

[40] M. H. Gordon, "The mechanism of the antioxidant action in vitro," in Food Antioxidants, B. J. E. Hudson, Ed., pp. 1-18, 1990.

[41] A. Noriham, A. S. Babji, and A. Aminah, "Determination of antioxidative activities of selected Malaysian plant extracts," Asean Food Journal, vol. 13, pp. 193-199, 2004.

[42] M. Yoshino and K. Murakami, "Interaction of iron with polyphenolic compounds: application to antioxidant characterization," Analytical Biochemistry, vol. 257, no. 1, pp. 40-44, 1998.

[43] J. P. E. Spencer, A. Jenner, O. I. Aruoma et al., "Intense oxidative DNA damage promoted by L-DOPA and its metabolites: implications for neurodegenerative disease," FEBS Letters, vol. 353, no. 3, pp. 246-250, 1994.

[44] J. M. McCord and E. D. Day, "The deoxyribose assay: an assay both for free hydroxyl radical and for site specific hydroxyl radical production," FEBS Letters, vol. 86, pp. 139-142, 1987.

[45] N. Cotelle, J. L. Bernier, J. P. Catteau, J. Pommery, J. C. Wallet, and E. M. Gaydou, "Antioxidant properties of hydroxyflavones," Free Radical Biology and Medicine, vol. 20, no. 1, pp. 35-43, 1996.

[46] A. P. Wickens, "Ageing and the free radical theory," Respiration Physiology, vol. 128, no. 3, pp. 379-391, 2001.

[47] P. Cos, L. Ying, M. Calomme et al., "Structure-activity relationship and classification of flavonoids as inhibitors of xanthine oxidase and superoxide scavengers," Journal of Natural Products, vol. 61, no. 1, pp. 71-76, 1998.

[48] G. M. Nardi, R. Felippi, S. DalBó et al., "Anti-inflammatory and antioxidant effects of Croton celtidifolius bark," Phytomedicine, vol. 10, no. 2-3, pp. 176-184, 2003.

[49] M. Paździoch-Czochra and A. Wideńska, "Spectrofluorimetric determination of hydrogen peroxide scavenging activity," Analytica Chimica Acta, vol. 452, no. 2, pp. 177-184, 2002.

[50] I. Gülçin, "Antioxidant and antiradical activities of Lcarnitine," Life Sciences, vol. 78, no. 8, pp. 803-811, 2006.

[51] M. Agarwal, V. K. Srivastava, K. K. Saxena, and A. Kumar, "Hepatoprotective activity of Beta vulgaris against $\mathrm{CCl}_{4}$ induced hepatic injury in rats," Fitoterapia, vol. 77, no. 2, pp. 91-93, 2006.

[52] H. De Groot and H. Sies, "Cytochrome P-450, reductive metabolism, and cell injury," Drug Metabolism Reviews, vol. 20, no. 2-4, pp. 275-284, 1989.

[53] K. Kohli and G. K. Jain, Herbal Drugs: Regulation across the Globe, Jaypee Brothers Medicinal, New Delhi, India, 2006.

[54] U. Bandyopadhyay, D. Das, and R. K. Banerjee, "Reactive oxygen species: oxidative damage and pathogenesis," Current Science, vol. 77, no. 5, pp. 658-666, 1999.

[55] C. G. Fraga, B. E. Leibovitz, and A. L. Tappel, "Halogenated compounds as inducers of lipid peroxidation in tissue slices," Free Radical Biology and Medicine, vol. 3, no. 2, pp. 119-123, 1987. 
[56] C. C. Lin, M. H. Yen, T. S. Lo, and J. M. Lin, "Evaluation of the hepatoprotective and antioxidant activity of Boehmeria nivea var. nivea and $B$. nivea var. tenacissima," Journal of Ethnopharmacology, vol. 60, no. 1, pp. 9-17, 1998.

[57] M. Kanter, I. Meral, S. Dede et al., "Effects of Nigella sativa L. and Urtica dioica L. on lipid peroxidation, antioxidant enzyme systems and some liver enzymes in $\mathrm{CCl}_{4}$-treated rats," Journal of Veterinary Medicine Series A, vol. 50, no. 5, pp. 264-268, 2003.

[58] M. Y. Hung, T. Y. C. Fu, P. H. Shih, C. P. Lee, and G. C. Yen, "Du-Zhong (Eucommia ulmoides Oliv.) leaves inhibits $\mathrm{CCl}_{4}$-induced hepatic damage in rats," Food and Chemical Toxicology, vol. 44, no. 8, pp. 1424-1431, 2006.

[59] A. Jadon, M. Bhadauria, and S. Shukla, "Protective effect of Terminalia belerica Roxb. and gallic acid against carbon tetrachloride induced damage in albino rats," Journal of Ethnopharmacology, vol. 109, no. 2, pp. 214-218, 2007.

[60] S. A. Ganie, E. Haq, A. Masood, and M. A. Zargar, "Antioxidant activities of methanolic rhizome extract of Podophyllum hexandrum against CCl4-induced kidney \& lung injury in rats," Journal of Pharmacology and Toxicology, vol. 5, no. 7, pp. 334-342, 2010. 


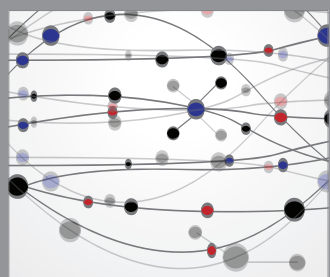

The Scientific World Journal
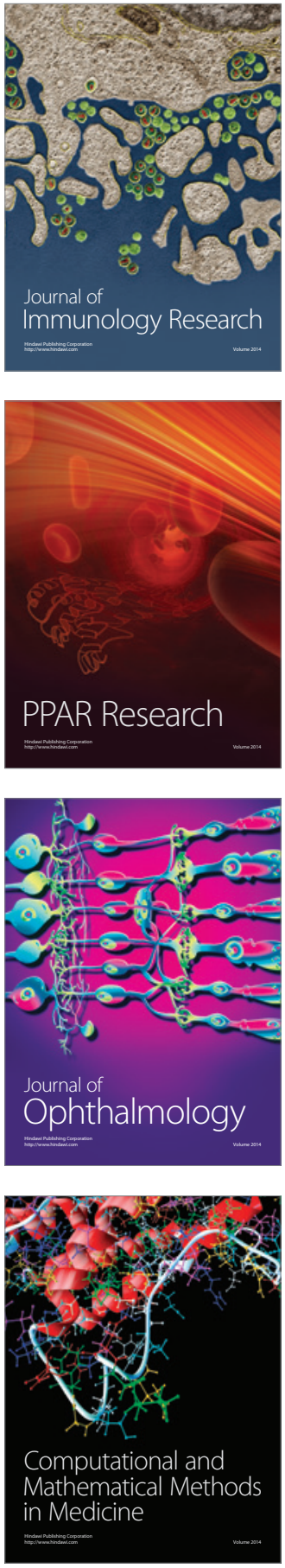

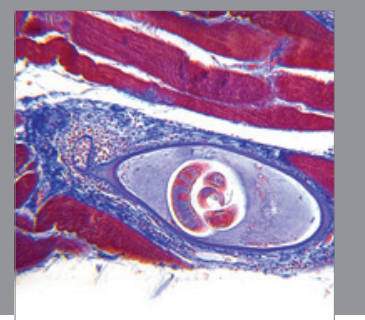

Gastroenterology

Research and Practice
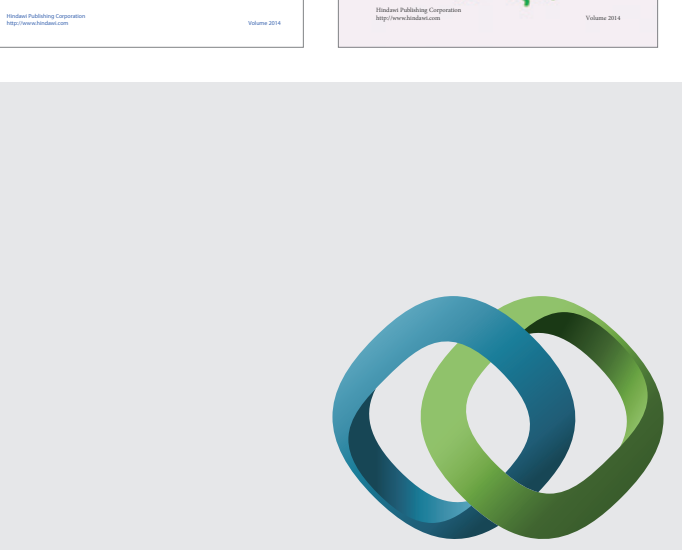

\section{Hindawi}

Submit your manuscripts at

http://www.hindawi.com
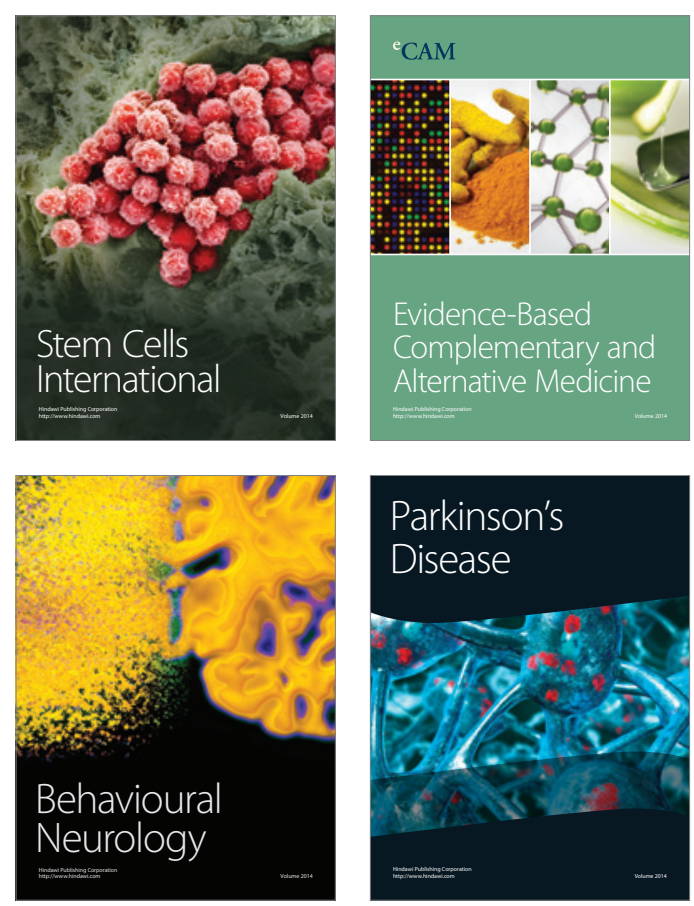

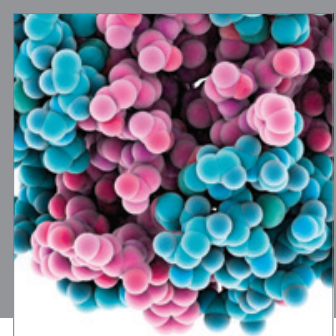

Journal of
Diabetes Research

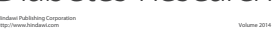

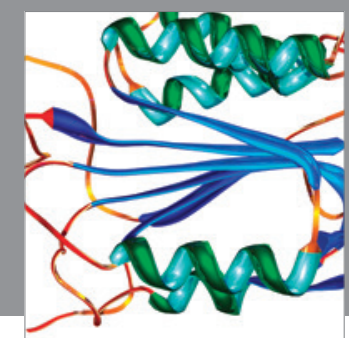

Disease Markers
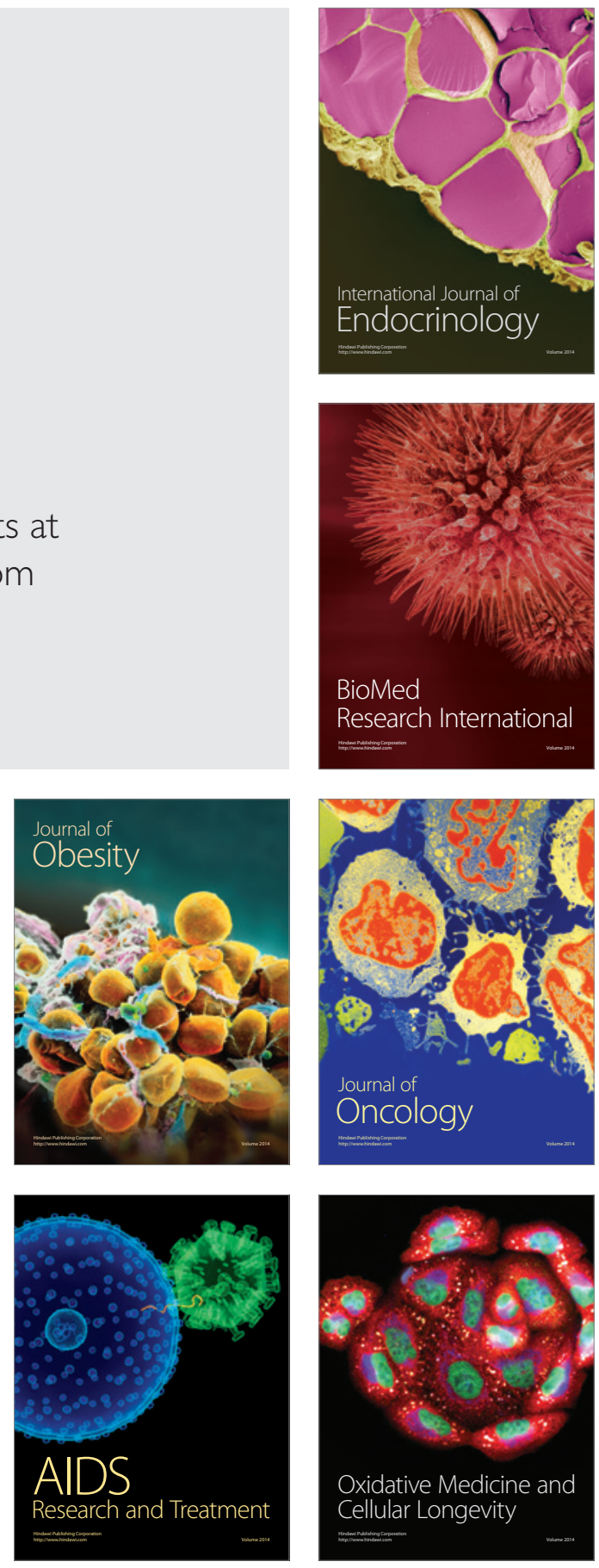